NBER WORKING PAPER SERIES

\title{
THE EFFECTS OF MINIMUM WAGES \\ ON EMPLOYMENT: THEORY AND \\ EVIDENCE FROM THE UK
}

\author{
Richard Dickens \\ Stephen Machin \\ Alan Manning
}

Working Paper No. 4742

\section{NATIONAL BUREAU OF ECONOMIC RESEARCH 1050 Massachusetts Avenue \\ Cambridge, MA 02138 \\ May 1994}

The authors would like to thank Danny Blanchflower, David Card, Alan Krueger and participants in seminars at Dartmouth, Manchester and Princeton for helpful comments, the ESRC for financial support and the Department of Employment for giving us access to the New Earnings Survey microdata. The results reported and the views expressed here do not necessarily reflect those of the Department of Employment, or the National Bureau of Economic Research. This paper is part of NBER's research program in Labor Studies. 
NBER Working Paper \#4742

May 1994

\title{
THE EFFECTS OF MINIMUM WAGES \\ ON EMPLOYMENT: THEORY AND \\ EVIDENCE FROM THE UK
}

\begin{abstract}
Recent work on the economic effects of minimum wages has stressed that the standard economic model, where increases in minimum wages depress employment, is not supported by the empirical findings in some labour markets. In this paper we present a theoretical framework which is general enough to allow minimum wages to have the conventional negative impact on employment, but which also allows for the possibility of a neutral or a positive effect. The model structure is based on labour market frictions which give employers some degree of monopsony power. The formulated model has a number of empirical implications which we go on to test using data on industry-based minimum wages set by the UK Wages Councils between 1975 and 1990. Some strong results emerge: minimum wages significantly compress the distribution of eamings and, contrary to conventional economic wisdom but in line with several recent studies, do not have a negative impact on employment. If anything, the relationship between minimum wages and employment is estimated to be positive.
\end{abstract}

Richard Dickens

Centre for Economic Performance

London School of Economics

Houghton Street

London WC2A 2AE

UNITED KINGDOM

Alan Manning

London School of Economics

Houghton Street

London WC2A 2AE

UNITED KINGDOM
Stephen Machin

University College London

London WC1E 6BT

UNITED KINGDOM

and Harvard University 


\section{Introduction}

There is an enormous body of research, both theoretical and empirical, on the employment effects of minimum wages ${ }^{1}$, but, on the whole, there is very little interaction between the two sides of the literature. This is likely to have a number of disadvantages. First, many theoretical models used to inform thinking about the likely effects of minimum wages have predictions that are at variance with what is seen in reality. A good example of this is the inability of some theoretical models to explain the existence of a spike in the empirical wage distribution at the legal minimum. Secondly, empirical investigations without a theoretical framework run the risk of using procedures and making inferences which may seem plausible but do not necessarily stand up very well to theoretical scrutiny. For example, it is sometimes argued that looking at workers or firms with very low wages is a good way of researching the employment effects of minimum wages. But, in the model that we present in this paper, following this approach will lead to a negative bias in the estimated impact of minimum wages on employment.

In this paper, our aim is to present a theoretical framework which is flexible enough to make predictions about the effects of minimum wages that are not obviously at odds with reality, but that can also be used to inform empirical work. We think that a satisfactory theoretical model must satisfy a number of criteria. First, it must be general enough for minimum wages to have either positive or negative effects on employment. Too often, the only theoretical models used are competitive ones in which the only empirical question is not "do minimum wages reduce employment?" but "how much?". This is particularly important

1 See Brown, Gilroy and Kohen (1982) for a fairly comprehensive survey of the US evidence to that date. 
given that a large and growing batch of recent studies (Card, 1992a, 1992b; Katz and Krueger, 1992; Machin and Manning, 1992; Card, Katz and Krueger, 1993; Card and Krueger, 1993) all claim that minimum wages may actually increase employment (at least for relatively small changes in the minimum wage), a prediction which is totally at odds with the vast majority of the theoretical models used. ${ }^{2}$ The most common theoretical model used to generate positive effects of minimum wages on employment is a monopsony model, and this is the approach we adopt here, albeit in a different way to the "old-style" textbook monopsony model.

Monopsony is currently not a popular model of the labour market. For example, it has been claimed that "there is little evidence that it is important in modern-day low-wage labour markets" (Brown, Gilroy and Kohen, 1982, page 489) although exceptions are sometimes noted (the most commonly cited exception is the US market for nurses: see Sullivan, 1989). One should note that this viewpoint is very much based on the companytown example of monopsony which is cited in many labour economics textbooks. There are other theoretical routes whereby employers can establish a degree of monopsony power and our model is based on one of these. We present a model based on the notion that there are substantial frictions in the labour market and this means that the labour supply to an individual firm will not be perfectly elastic which means that firms, to some extent, possess some degree of monopsony power. ${ }^{3}$

Our second requirement is that we think any theoretical model should be able to

2 A notable exception is the efficiency wage model of Calvo and Wellisz (1979).

3 See Machin, Manning and Woodland (1993) for an attempt to document the extent of monopsony power in a low wage labour market. 
explain the spike in observed wage distributions at the minimum wage. Our model of a labour market with frictions naturally produces this prediction. One should also recognise that there are other competitive explanations of this phenomenon, notably that firms adjust non-wage compensation or that the labour markets studied are made up of many different sub-markets a fraction of which have wages equal to the minimum (Teulings, 1991). In this paper we do not address whether the spike is better explained by these theories than ours although it should be noted that Holzer, Katz and Krueger (1991) claim that minimum wage jobs do not offer the same level of utility as "surrounding" jobs, and Katz and Krueger (1992) and Card and Krueger (1993) found that few fast food restaurants reduced non-wage benefits when confronted with an increase in the minimum wage.

In the next section of the paper we outline our theoretical model of a labour market characterised by frictions. We show that there is generally an optimal minimum wage and discuss the factors that determine this optimum. In section III, we then consider the implications of our model for empirical work on the employment effects of minimum wages. We argue that many cross-section studies are completely worthless and that the so-called "impact studies" may also have problems. In contrast, time-series and panel studies emerge more favourably. In section IV we extend some of our earlier empirical work (Machin and Manning, 1992) and look in some detail at the employment effects of the minimum rates of pay set by the UK Wages Councils using panel data from the 1970s and 1980s. Finally, section $\mathrm{V}$ offers some concluding remarks. 


\section{II.The Model}

In this section we present a simple model of a labour market with frictions which is general enough to allow minimum wages to have either a positive or a negative effect on employment, and produces predictions about the effects of minimum wage legislation on the distribution of wages that are at least outwardly consistent with what we observe. Assume firm i has a marginal revenue product of labour curve given by:

$$
M R P L_{i}=A_{i} \cdot L_{i}^{-e}
$$

where $\mathrm{L}$ is employment and $\mathrm{A}$ is a shock to the MRPL which reflect demand or productivity shocks. If the labour market was perfectly competitive then the elasticity of the labour demand curve would be $(1 / \epsilon)$.

Turning to the labour supply curve to the firm, we assume that the fraction of aggregate labour supply, $L$, arriving at firm $i, L_{i}$, depends on the wage offered, $W_{i}$, a supply shock, $B_{i}$, and the distribution of wages $F(W)$ according to some function:

$$
L_{i}=\phi\left(W_{i} B_{i} F(W)\right) \cdot L
$$

While (2) is very general, it does not lead to an analytically tractable model. So, in the theoretical section, we assume that the average wage is sufficient for the effect of the wage distribution on the labour supply to a firm and, in particular that the labour supply is of the form:

$$
L_{i}=\left(\frac{W_{i}}{B_{i} W}\right)^{\frac{1}{\theta}} \cdot L
$$

where $\mathrm{W}$ is the average wage. (3) can be thought of as analogous to the Dixit and Stiglitz 
(1977) specification of the demand curve facing an individual firm in models of monopolistic competition. The assumption that labour supply to a firm depends only on its wage relative to the average is a strong one; in general, other features of the wage distribution may also be important. In the current model, the effect of the assumption that labour supply depends only on the average wage means that a rise in the minimum wage has the same effect on the wages paid by all firms paying above the minimum. This is an assumption that we seek to investigate later on.

If the labour market is perfectly competitive then $\theta=0$ but if $\theta>0$ the market is, to some extent, monopsonistic. It is the potential of this which allows minimum wages to raise employment. It is somewhat unconventional to assume the existence of monopsony power in labour markets. However, the presence of labour market frictions means that employers cutting wages do not instantaneously lose all their workers and, as such, it is plausible to assume they have some local monopsony power. ${ }^{4}$ It is worth stressing that this source of monopsony power is very different from the usual company-town example of monopsony (indeed, a good example of this is that it is probably the case that smaller firms are more likely to be characterised by frictions: see Burdett and Mortensen, 1989, for more details).

$B_{i}$ is a firm specific labour supply shock which could represent differences in the nonpecuniary attractiveness of work in different firms. An alternative, more general

4 Some arguments along these lines are presented in more detail in Machin and Manning (1992) and Machin, Manning and Woodland (1993). One can debate whether this monopsony power exists only in the short-run. Our model, which is static for analytical convenience, cannot address this issue, but because workers are continually leaving and entering the labour market it is not unreasonable to believe that some firms do have some monopsony power in the long-run. 
interpretation, is that it represents differences in the wages paid in different firms necessary to prevent shirking or differences in the bargaining power of workers in different firms. It is the existence of this shock that ensures that the model generates a distribution of wages even if the labour market is perfectly competitive.

Finally we assume that aggregate labour supply is given by $\mathrm{L}=\mathrm{L}_{0} \mathrm{~W}^{\downarrow} \cdot \psi=0$ means that, although an individual firm can raise its labour supply by raising its wage, this is entirely at the expense of other firms. On the other hand, if $\psi>0$, then aggregate labour supply also increases. Defining $\mu=1-\psi \theta$ and rearranging (3) we have:

$$
W_{i}=L_{0}^{-\theta} B_{i} W^{\mu} L_{i}^{\theta}
$$

First, let us consider the equilibrium when there are no minimum wages. Each firm chooses the level of employment where the MRPL equals the marginal cost of labour which, from (4) is given by:

$$
M C L_{i}=(1+\theta) L_{0}^{-\theta} B_{i} W^{\mu} L_{i}^{\theta}
$$

Equating (5) and (1) gives employment in firm $i$ as:

$$
L_{i}=\left[\frac{A_{i} L_{0}^{\theta}}{(1+\theta) B_{i} W^{\mu}}\right]^{\frac{1}{\theta+\epsilon}}
$$

and from (4) the wage is:

$$
W_{i}=(1+\theta)^{\frac{-\theta}{\theta+e}} L_{0}^{\frac{-\theta \varepsilon}{\theta+c}} A_{i}^{\frac{\theta}{\theta+e}} B_{i}^{\frac{\varepsilon}{\theta+e}} W^{\frac{\epsilon \mu}{\theta+e}}
$$

(6) and (7) are easy to understand. Revenue shocks, A, have a positive effect on employment while supply shocks, B, have a negative effect. In contrast, both A and B are 
positively related to wages although, as we would expect, A only has an effect to the extent that the labour market is not perfectly competitive (where $\theta>0$ ). ${ }^{5}$ The distribution of wages depends on the distribution of $\left(A_{i}, B_{i}\right)$ across firms. For analytical convenience we assume that these shocks are joint log-normally distributed. In what follows it is convenient to transform the shocks into two other shocks. First define:

$$
X_{i}=A_{i}^{\frac{\theta}{\theta+\epsilon}} B_{i}^{\frac{\epsilon}{\theta+\epsilon}}
$$

and then define:

$$
V_{1}=B_{i} X_{i}^{-p}
$$

where $\rho$ is defined by $E\left(\ln \mathrm{B}_{\mathrm{i}} \mid \ln \mathrm{X}_{\mathrm{i}}\right)=\rho \ln \mathrm{X}_{\mathrm{i}}$. By construction, $\mathrm{X}_{\mathrm{i}}$ and $\mathrm{V}_{\mathrm{i}}$ are independent. Using (8) and (9) to replace $A$ and $B$ by $X$ and $V$ we can derive:

$$
\begin{gathered}
L_{i}=\left[W^{-\mu} L_{0}^{\theta}(1+\theta)^{-1}\right]^{\frac{1}{\theta+\epsilon}} V_{i}^{-\frac{1}{\theta}} X_{i}^{\frac{1-p}{\theta}}=W^{\frac{-\mu}{\theta+\epsilon}} U X_{i}^{\frac{1-p}{\theta}} \\
W_{i}=\left[L_{0}^{\epsilon}(1+\theta)\right]^{\frac{-\theta}{\theta+\epsilon}} W^{\frac{\mu \epsilon}{\theta+\epsilon}} X_{i}=W_{0} W^{\frac{\mu \epsilon}{\theta+\epsilon}} X_{i}
\end{gathered}
$$

where $W_{0}$ and $U_{i}$ are defined to be the other terms on the RHS of (10) and (11). $X_{i}$ can be thought of as a firm-specific wage shock. Because of the existence of the employer-size wage effect (see Brown and Medoff, 1989) we have strong reason to believe that $\rho<1$ so that there is a positive correlation between wages and employment. If we observed a labour

s It should be noted that there is considerable empirical evidence that wages do depend on variables related to firm and industry productivity even in the non-union sector (e.g. Nickell and Wadhwani, 1990; Dickens and Katz, 1987) which is consistent with the monopsony model. 
market in the absence of minimum wages we would observe a scatter of points about a positively sloped line relating the log wage to log employment.

Now consider what happens if a minimum wage of $\mathrm{W}^{\bullet}$ is introduced. This means that a firm can be in one of three qualitatively distinct regimes. In the first, which we will call the Unconstrained Regime, the firm pays a wage above the minimum and the employment and wage rates of (10) and (11) continue to be relevant. Note that if $\mu \neq 0$, the change in $\mathrm{W}$ caused by the minimum wage will mean that the set of firms initially paying above $\mathrm{W}^{*}$ will not be the same as the ones now paying above $W^{\circ}$ and that although the unconstrained firms pay above the minimum they are still affected by it. For an unconstrained firm we have something like the situation depicted in Figure 1 where $M R P L_{1}$ represents a firm in this regime. From (11), a firm will be in this regime if:

$$
X_{1} 2 X_{+} \equiv W^{*} W_{0}^{-1} W^{\frac{-\mu \varepsilon}{\theta+\epsilon}}
$$

For a firm with $\mathrm{X}_{i}$ slightly below $\mathrm{X}_{+}$, say with $\mathrm{MRPL}_{2}$ in Figure 1 it is optimal to pay $\mathrm{W}^{*}$ and accept all workers forthcoming at this wage. We will refer to these as supplyconstrained firms. Employment in these firms can be found by substituting $W_{i}=W^{*}$ in (4). Using (12) to write $\mathrm{W}^{*}$ in terms of $\mathrm{X}_{+}$we can derive the following employment rule for these firms:

$$
L_{1}=W^{\frac{-\mu}{\theta+e}} U_{i} \cdot X_{i}^{\frac{-p}{\theta}} X^{\frac{1}{\theta}}
$$

By comparison of (13) with (10) we note that, for a given level of W, employment in these firms will be higher with the minimum wage than without. The explanation for this is simple. A firm initially paying slightly below $W^{*}$ has $M R P L_{i}>W_{i} ;$ a slight increase in the 
wage then increases labour supply while still ensuring it is profitable for the employer to employ these extra workers. Consequently, we know that employment must increase for firms in this situation.

But if the MRPL curve is sufficiently low then the firm will be in a situation where it is not profitable for the firm to employ all the workers forthcoming at $\mathrm{W}$. We will refer to these firms as demand-constrained. These firms choose employment so that $\mathrm{MRPL}_{\mathrm{i}}=\mathrm{W}^{*}$ which is depicted by MRPL in Figure 1 . Using (8) and (9) to eliminate $A_{i}$ from (1) and using (12) to write $\mathrm{W}^{*}$ in terms of $\mathrm{X}_{+}$we can derive:

$$
L_{l}=W^{\frac{-\mu}{\theta+\varepsilon}} U_{i}(1+\theta)^{\frac{1}{\epsilon}} X_{i}^{\frac{1-p}{\theta}+\frac{1}{\epsilon}} X_{+}^{\frac{-1}{6}}
$$

as the employment rule for firms in this regime. A firm is in this regime when the marginal revenue product of the labour supply at $\mathrm{W}^{\circ}$ is less than $\mathrm{W}^{*}$. By manipulating (1) and (4), this occurs when:

$$
X_{i}<W^{*} L_{0}^{\frac{\theta \varepsilon}{\theta+\varepsilon}} W^{\frac{-\mu \varepsilon}{\theta+e}}=(1+\theta)^{\frac{-\theta}{\theta+e}} X_{+}=X_{-}
$$

The employment level of firms in this regime will rise with the introduction of the minimum wage if $X_{i}$ is close to $X$. but will fall if $X_{i}$ is very low. This can be readily understood by inspection of Figure 1.

We can now summarize what happens to wages and employment in each firm in the presence of minimum wages: 
Unconstrained: $\quad$ If $\quad X_{i}>X_{+}$

$$
\begin{aligned}
& W_{i}=W_{0} W^{\frac{\mu e}{\theta+e}} X_{i} \\
& L_{l}=U_{i} W^{\frac{-\mu}{\theta+e}} X_{i}^{\frac{1-p}{\theta}}
\end{aligned}
$$

Supply-Constrained: If $\quad(1+\theta)^{\frac{-0}{\theta+e}} X_{+}<X_{t}<X_{+}, \quad W_{l}=W^{*} \quad$ and

$$
L_{l}=U_{t} W^{\frac{-\mu}{\theta+e}} X_{t}^{\frac{-p}{\theta}} X^{\frac{1}{\theta}}
$$

Demand Constrained: If $\quad X_{i}<(1+\theta)^{\frac{-\theta}{\theta+e}} X_{+}, \quad W_{i}=W^{*}$ and

$$
\begin{aligned}
L_{i} & =U_{i} W^{\frac{-\mu}{\theta+\epsilon}}(1+\theta)^{\frac{1}{\epsilon}} X_{i}^{\frac{1-p}{\theta}+\frac{1}{\epsilon}} X_{+}^{-\frac{1}{\epsilon}} \\
& =U_{i} W^{\frac{-\mu}{\theta+\epsilon}}(1+\theta)^{\frac{1}{\theta+\epsilon}} X_{i}^{\frac{1-p}{\theta}+\frac{1}{\epsilon}} X_{-}^{-\frac{1}{\epsilon}}
\end{aligned}
$$

We can gain some insight into the employment effects of a minimum wage by considering Figure 2. Assume, for simplicity that $\mu=0$. The line LL gives the average relationship between employment and $\mathrm{X}_{\mathrm{i}}$ before the introduction of a minimum wage. Now suppose a minimum wage is introduced that induces a cut-off point $\mathrm{X}_{+}$between the unconstrained and supply-constrained regimes. Only employment in firms with $X_{i}$ below $X_{+}$are affected; let us denote the new level of employment in these firms by the dotted line. For all supplyconstrained firms, employment is raised. Employment gains start to fall once we enter the demand-constrained firms and are negative for the firm with the lowest $X_{i}$. It should be obvious from this that we cannot tell, a priori, the effect on total employment except in some special cases. If $\theta=0$ the labour market is perfectly competitive, the supply-constrained 
regime disappears and all demand-constrained firms suffer employment losses. But as long as $\theta>0$ some degree of minimum wage legislation can raise employment. The picture of Figure 2 needs modification if $\mu \neq 0$ as then LL itself moves with the minimum wage but the basic ideas remain the same.

Another point that should be noted is that it is reasonable to believe that a minimum wage affects different firms in different ways; in our model low productivity firms are likely to reduce employment while higher productivity firms are expected to increase it. This has some implications for empirical research that we will discuss below.

It should also be apparent that there is some "optimal" minimum wage which maximises employment. ${ }^{6}$ There is some interest in finding out how high is the optimal minimum wage and how it varies with the parameters of the model. Not surprisingly, the optimal minimum wage depends on the average values of A and B which will change over time with the general level of productivity in the economy. But we can also use the model to compute the optimal level of two other measures of the intensity of minimum wage legislation; the proportion of workers paid the minimum (which we will call the spike) and the ratio of the minimum to average earnings (which we will call toughness). In the Appendix, the following result is proved.

Result

Employment relative to the level in the absence of minimum wage can be written as a function of $\{\epsilon, \theta, \rho, \sigma, \mu\}$ and either the spike or toughness.

Proof: See Appendix.

- It should be noted that employment maximisation is not necessarily the same as welfare maximisation in the current model but the latter is complicated to calculate. 
This result shows that one can say something about the likely effects of a minimum wage on employment once one makes assumptions about a relatively small set of parameters describing the economy. To give some idea of the likely optimal minimum wage and the employment benefits from it we conducted some simulations. These should be thought of as illustrative only as the real world wage distribution does not seem well-modelled by the log-normal. ${ }^{\top}$

As a base case we made the following assumptions about parameters. For the sensitivity of wages to employer size we used $\theta=0.2$. For the standard deviation of wages in the absence of minimum wages we assumed $\sigma=0.3$. For the elasticity of the labour demand curve we assumed $\epsilon=0.5$ which is a compromise between the evidence that the labour demand elasticity is one and the value that one would expect given a Cobb-Douglas production function and the share of labour in output. Finally, we start by assuming that $\mu=0$ and $\rho=0$ so that there are no knock-on effects. For this base case the optimal spike is $12 \%$ which corresponds to a toughness measure of $66 \%$. However the employment gains relative to not having a minimum wage are very small, being in the order $0.5 \%$ and the average wage gain is $0.8 \%$ although, of course, the wage gain for those affected is considerably larger. In general, employment is not very sensitive to the minimum wage in our base case and employment is effectively constant for a wide range of minimum wages.

We then investigated the sensitivity of these conclusions to variations in the

7 In an earlier version of this paper (Dickens et al., 1993) we also estimated employment effects of minimum wages based on the Meyer-Wise (1983a, 1983b) approach of predicting employment effects by trying to estimate what the wage distribution would look like in the absence of a minimum wage. Results proved very sensitive to distributional assumptions and assuming log-normality of pay distributions of Wages Council workers proved to be very unsatisfactory. 
parameters. These results are presented in Table 1. First, we consider variation in $\theta$, which measures the elasticity of the labour supply curve to the individual firm. Not surprisingly, as the labour supply curve becomes more inelastic and the extent of monopsony power increases, the optimal minimum wage increases. We next consider a rise in the variance of wages. In this case low dispersion of wages is associated with high optimal minimum wages. This is not surprising because the optimal minimum wage differs across firms. If there is little dispersion in wages one can "fine-tune" the minimum wage to what is desirable for the small range of wages whereas if dispersion is high a minimum wage that is good for some will have undesirable effects for others. One implication of this is to have different minimum wages for different groups of workers. Next we consider the effect of the knockon parameter $\mu$. Not surprisingly the higher this parameter the larger will be the effect of the minimum wage on wages higher up the distribution and the lower the employment effect. Hence the optimal minimum wage decreases as $\mu$ increases.

Finally, we consider varying the elasticity of labour demand. The optimal minimum wage is increasing in the elasticity of demand although the effects are very small. The intuition for this is the following. If labour demand is completely inelastic then employment will be the same whatever the level of the minimum wage. The possibility for employment gains only arises once there is some elasticity in the labour demand curve. However, it is also the case that employment become more sensitive to the minimum wage as the elasticity increases which means that an inappropriate minimum wage may have large effects on employment. We also considered varying $\rho$ but this seemed to have little effect on outcomes and we lack any intuition about what its effects should be.

We have discussed how we can use the theoretical framework described above to 
discuss the question of the optimal minimum wage. We now show how we can use it to inform empirical work on the employment effects of minimum wages.

\section{Empirical Implications}

In this section we consider what light the theoretical model proposed above can shed on empirical approaches to the analysis of the employment effects of minimum wages.

\section{a. Longitudinal Studies}

The implications of the theoretical model presented above can be summarised in the following equations:

$$
\begin{gathered}
L_{h}=L\left(A_{j p} B_{j p}\left(W_{k}^{*} / W_{n}\right)\right) \\
\left(W_{k}^{*} / W_{p}\right)=W\left(A_{j} B_{k r} W_{k}^{*}\right)
\end{gathered}
$$

In (23) and (24) the subscript $j t$ denotes economic agent $j$ (individual, industry, region, firm etc.) in period $t, A$ denotes the demand shock, $B$ the supply shock, $W^{*}$ the minimum wage and $W$ the average wage. We choose to condition employment on the toughness of the minimum wage (defined $\left.\mathrm{W}^{*} / \mathrm{W}\right)^{8}$ rather than the level of the minimum wage because a given

8 This is the minimum wage variable used in most empirical studies where it is sometimes weighted by the fraction of workers covered by the minimum. 
level of the minimum is likely to have a different effect on employment for different levels of (A, B) so that a highly non-linear empirical specification would be essential if the effect of the minimum wage was to be summarized merely by the level.

One implication that emerges immediately from (23) and (24) is that looking for the employment effects of a minimum wage in a cross-section where there is no variation in the minimum is basically a pointless exercise. Some U.S. studies have adopted this methodology and claim it to be valid by arguing that minimum wages should have less of an effect in high wage states. Freeman (1980, page 8) concluded that studies that do this provide "at most a weak test of the effect of the minimum" but we feel that is too generous. If there is no variation in $\mathrm{W}^{*}$, the employment equation (23) is unidentified. If some element of $\mathrm{A}$ is excluded from the employment equation this will tend to lead to negative estimated effects of the minimum on employment as a high $\mathrm{A}$ raises average wages and employment in the labour market. However, if some element of $B$ is excluded then this will tend to lead to positive estimated employment effects as a high $B$ raises the average wage and depresses employment. Either will clearly reflect a spurious correlation between employment and minimum wages.

This means that, not surprisingly, one needs some variation in the minimum wage to estimate its employment effects. This variation can be over time or across a group of industries at a point in time or ideally has both sorts of variation. We use data satisfying these criteria in the empirical analysis below where we use panel data on industry-based minimum wages and employment from the UK in the 1970s and 1980s (see also Neumark and Wascher, 1992, who use US panel data by state). It should also be apparent from the discussion that it is crucially important to control properly for demand and supply shocks or 
alternatively that toughness should be instrumented using variables which affect the minimum but are uncorrelated with those shocks.

\section{b. Impact Studies}

These studies originated in investigations of the employment effects of increases in the US federal minimum wage (e.g. Lester, 1960) and the method has recently been revived by Katz and Krueger (1992) and Card and Krueger (1993). They look at how the effect of a change in the minimum wage differs across firms in the fast-food industry. If a negative (positive) correlation between the increase in wages and employment growth is found it is concluded that minimum wages reduce (increase) employment. Inspection of Figure 3 should show the potential dangers with this inference. Suppose there are no changes in the distribution of demand and supply shocks across firm and there are no knock-on effects. Then the model described above predicts that the introduction of a minimum wage will lead to employment gains for firms that have to raise their wages only slightly to the minimum and falls for those firms that have to increase their wages the most.

It should be noted that the relationship between wage growth and employment change is non-monotonic so that there may be a negative or a positive correlation between wage growth and employment growth' but, whatever the result, this tells us nothing about the total employment effects of minimum wages for which we need to add up the employment gains and losses across firms i.e. we need to integrate the area between the two lines in Figure 3 (weighting by the distribution of $X_{i}$ ). For example, if all the firms were on the downward

9 Matters are complicated by the fact that the relationship between wage growth and employment growth is non-monotonic so that a linear relationship is inappropriate. 
sloping portion of the line in Figure 3 but above the horizontal axis one would find a negative correlation between wage change and employment change but the net employment effect of the minimum wage is positive. Often impact studies are not able to add up the employment changes across firms that are due to the minimum wage as they have no way of controlling for aggregate industry demand or supply shocks that may be affecting all firms at the same time as the change in the minimum wage. However, it should be noted that the study of Card and Krueger (1993) does allow for this by considering characteristics of a similar labour market which was unaffected by the changes in the minimum as a control.

The above discussion has been in terms of the introduction of a minimum wage, but a similar problem arises if we consider the effect of increasing the minimum wage. As long as the increase in the minimum is not too large, for firms that increase wages from the old to the new minimum we would expect to find some negative and some positive employment effects.

In this section, we have argued that there are some potential problems in interpreting the results of impact studies. The problem arises because our theoretical model predicts that different firms will respond in different ways to changes in the minimum wage whereas this approach has implicitly has to assume that all firms will respond in the same way. Such an approach is sensible only if the competitive model is correct. The bias is likely to be towards finding a negative correlation between wage and employment growth, a bias that is likely to be particularly large if one focuses on the lowest wage firms. Given this, it is perhaps surprising that Krueger and Katz (1992) and Card and Krueger (1993) fail to find such an effect, and it is possible to argue that their conclusions may understate the positive effect of the minimum wage on employment. 
In this section, we have discussed a number of ways of empirically estimating the employment effects of minimum wages. In the next section, we try to implement these approaches using information on the UK system of minimum wages, the Wages Councils.

\section{The Wages Councils}

\section{a. The Data}

The Wages Councils were established by Winston Churchill in 1909 to protect the pay of workers in the so-called 'sweated' trades. They set minimum wage rates in a number of different industries. Over the years, the number of industries covered first increased (to a peak of about 60 covered sectors in the early 1960s) and then decreased and by 1992 the 26 remaining Wages Councils set minimum wages for approximately 2.5 million workers in low paid sectors (mostly in hotels and catering, retail, clothing manufacture and hairdressing but also in a number of very small industries). Until the 1986 Wages Act, the Councils generally set a myriad of minimum wages differentiated by age, occupation and region but since 1986 set only a single rate. The 1993 Trade Union Reform and Employment Rights Bill abolished the remaining 26 Councils so that from 1993 there is no form of minimum wages in operation in the UK. One of the Government's arguments for abolition was based on the claim that the minimum rates of pay set by the Councils were bad for employment (see Dickens et al., 1993).

The best source of information on workers covered by the Wages Councils is the annual New Earnings Survey (NES). This is an employer-reported 1\% sample of all workers who pay National Insurance contributions conducted in April each year. We have access to 
the data for the years 1975 to 1990 . There are two ways of identifying workers in Wages Council industries from the NES. First, employers are asked whether workers are covered by a Wages Council agreement. Secondly, we can use the detailed industrial and occupational information to work out who should be covered. Typically, the numbers obtained using the first method are less than the numbers obtained by the second method and there seems to be some degree of misclassification. For this reason, we prefer the numbers obtained from the second method. ${ }^{10}$ Only the relatively large Wages Councils have enough workers in the NES for the data to be considered reliable; the ones used in this study are reported in Table 2. A potential problem is that the 1986 Wages Act removed people under the age of 21 from the coverage of the Wages Councils. However, it seems that the adult minimum rates are still exerting a strong effect on youth wages (which is reminiscent of the US finding of Katz and Krueger, 1992, that the youth sub-minimum is rarely used), so we use total employment in the Wages Council industries in our empirical analysis.

A further concern is that the NES undersamples part-time workers as workers only pay National Insurance if they earn more than a certain amount ( $£ 56$ per week in 1993). So we also used employment figures derived from the Employment Gazette (EG). These have the advantage that they include part-time workers but have the disadvantage that the map between the industries and Wages Councils is not perfect. Table 2 summarizes our employment data. We present average employment based on both NES and EG figures and the correlation between the two. As can be seen, the correlation is low in some cases

10 Having said that, in some earlier work (Machin and Manning, 1992) we report some results using the former numbers and reach very similar conclusions to those reported below. 
(though this only seems to be a serious problem for the Councils we do not follow through the entire 1975-90 sample period) so it is important to check the strength of our results using both measures; we are careful to do this below.

For our wage variable we use the basic hourly wage. To construct toughness, our preferred measure of the impact of the minimum wage defined as the ratio of the minimum to the average wage, we also need a measure of the minimum wage in force at any particular time. After 1986 this is straightforward as a single rate was set but, prior to that date, we used the lowest adult minimum rate. The average level and change in toughness for each Wages Council is reported in Table 2 and the median toughness in each year is plotted in Figure 4. As can be seen, toughness of the minimum wage increased in the 1970s but decreased in the 1980s with the arrival in 1979 of a Government hostile to the idea of minimum wages.

\section{b. The Effect of the Wages Councils on the Wage Distribution}

In this section we investigate the effect of the minimum rates set by the Wages Councils on the distribution of wages. There are a number of reasons for being interested in this. First, some commentators have expressed doubts about whether the Wages Councils have any effect at all because of lack of enforcement. Secondly, we would like to have some idea of the effect of the minimum wage on wages further up the wage distribution.

We investigated this by estimating first-differenced regressions of the log hourly wage at each decile in the earnings distribution on the log of the minimum hourly wage, together with year dummies (the regressions are weighted by the employment numbers in each industry-year cell). The results are reported in Table 3. As would be expected, the effect 
of the minimum wage on earnings levels is strongest at the lowest deciles of the distribution. Effects are estimated to be insignificantly different from zero for the median and higher deciles in the distribution. As the bottom row of the Table testifies, there is a positive significant impact on the average wage.

Given that the minimum has a considerably smaller effect on higher earnings, raising the minimum wage would have the effect of strongly reducing the dispersion in earnings, a result that was also found in an earlier piece on the British Wages Councils by Machin and Manning (1992). For example, a first-differenced regression of the gap between the 90th and 10th percentiles of the $\log$ wage distribution on the $\log$ of the real minimum and time dummies produced a coefficient (standard error) of $-0.293(0.096)$ suggesting a $10 \%$ increase in the real minimum would reduce the $90-10$ log hourly wage differential by some $2.9 \%$.

\section{c. The Effect of the Wages Councils on Employment: Panel Data Estimates}

In this section we investigate the relationship between employment and minimum wages using our panel on the UK Wages Councils between 1975 and 1990 . We want to estimate an employment equation like that described in (23) above. Issues regarding the appropriate specification of the employment function raise the question of how to properly control for demand and supply shocks. We think of most supply shocks as coming from the aggregate labour market, so model these by including year and Wages Council dummies. Modelling demand shocks is somewhat more tricky, mainly because most Wages Council workers are employed in service sector industries for which we have no information on variables that we might expect to shift the revenue function (e.g. prices). We follow two strategies to try to control for demand shifts. First, we do have data on industry sales which 
will be related to the industry shocks, $A$, through the revenue function $R=A$. $L^{\alpha}$ so we include (appropriately instrumented) sales variables in our employment functions. Second, we allow for different employment trends in the Catering, Clothing and Retail sectors to control for sector-specific employment changes.

So, for Wages Council $\mathrm{j}$ in year $\mathrm{t}$, the model to be estimated is of the form:

$$
L_{j k}=f_{j}+\delta_{1}\left(W_{j}^{*} / W_{j h}\right)+\delta_{2} T M M E_{i}+\delta_{3} S A L E S_{j k}+\delta_{4} S E C T O R_{j k}+u_{k}
$$

where $f_{j}$ is a Council-specific fixed effect, TIME denotes a set of year dummies, SALES is the log of sales, SECTOR denotes a set of linear trends for Catering, Clothing and Retail and $\mathrm{u}$ is a random error. To eliminate the fixed effects we first-difference equation (25) to yield the employment growth equation

$$
\Delta L_{h}=8_{1} \Delta\left(W_{j}^{*} / W_{h}\right)+\delta_{2} \Delta T I M E_{i}+8_{3} \Delta S A L E S_{j h}+\delta_{4} \Delta S E C T O R_{j h}+\Delta u_{j}^{(26)}
$$

Equation (26) forms the basis for the empirical work, though we also present some further generalizations below.

In Table 4 we present a set of results based on estimating variants of (26) using the employment measure from the New Earnings Survey as the dependent variable. We report seven specifications that differ in their estimation method and in their inclusion of controls for supply and demand shocks.

Column (1) is a simple least squares regression of the change in log(employment) on the change in $\log$ (toughness) plus a set of year dummies. The coefficient on the toughness variable is estimated to positive and significantly different from zero with a t-ratio of 2.30 . Hence, the basic correlation between employment changes and changes in the toughness of 
minimum wages is not in line with the conventional viewpoint. Rather, it contradicts it directly and there is a positive association.

In the toughness specification of the bite of the Wages council minima that we adopt in this paper, there is an implicit assumption of equal and opposite regression coefficients on the minimum and average wage variables in the estimated employment equation. If the real minimum and the real average wage are included as separate arguments, their coefficients and standard errors are estimated as $.473(.191)$ and $-.167(.230)$ respectively. A formal Ftest of their restriction to the toughness variable has a p-value of 0.296 suggesting that the restriction is not rejected by the data.

In columns (2)-(4) of Table 4 we include different specifications of the demand shock variables (sector-specific trends, sales growth or both). In column (2) we include dummy variables for Clothing and Retail Councils (i.e. which are picking up employment trends in the first-differenced models). Their estimated coefficients are both estimated to be negative and significant suggesting slower employment growth over the sample period than in the Catering sector. The coefficient on $\log$ (toughness) is, however, barely altered by their inclusion and remains positive and significantly different from zero.

In columns (3) and (4) we control for sales growth (which is deflated by an aggregate price index to convert it to real terms) in our employment growth equation. It is evident that we cannot simply enter the contemporaneously dated sales variable as it is jointly determined with the dependent variable. We thus followed two routes, the first instrumenting current sales growth using the log of real sales dated $(t-2)$ (with the coefficient in the instrumentation equation allowed to vary in each cross-section) and the second to simply include sales growth 
dated (t-2) as.a regressor. ${ }^{11}$ Controlling for sales does not affect the nature of the reported results. Whilst sales is significantly associated with employment in the instrumented version, the coefficient on $\log$ (toughness) remains significant and positive in both specifications. There is clearly very little comfort here for those who claim that the Wages Council minimum pay rates were bad for employment in the 1975-90 time period.

In the remainder of the Table we use the log of the real minimum wage dated $t, t-1$, and $t-2$ as instruments for the log of toughness. This is to ensure that the employment variations come through the minimum wage changes and not through average wage changes. In all cases, the coefficients remain similar to those in columns (1)-(4) (they actually rise by a small magnitude) and remain significant at the $10 \%$ level or better. The validity of the choice of instruments also cannot be rejected: for example, in the column (5) model, a formal Sargan instrument validity test produced a $\chi^{2}(2)$ statistic of 2.52 for the overidentifying restrictions provided by the instruments which lies well beneath the $5 \%$ critical value of 5.99 .

Hence, the specifications in Table 4 present evidence that, counter to the conventional economic model, increases in Wages council minimum rates of pay were associated with improved employment in the 1978 to 1990 time period. There is no evidence whatsoever for the notion that minimum wage effects on employment were negative, and in statistical terms we can comprehensively reject a null hypothesis of an employment-minimum wage elasticity in the -.1 to -.2 range which was cited as typical of the earlier time-series based

1 The reason for dating at $(t-2)$ is that the MA(1) error induced by the first-differencing of the employment equation means that sales growth dated $(t-1)$ is not independent of the error term. 
evidence by Brown et al. (1982).

We conducted various tests of the robustness of these results. First, we used total employee hours as our dependent variable. Columns (1) and (2) of Table 5 report hours specifications that produce similar results to the analogous specifications in Table 4. In both cases the coefficient on the minimum wage variable is estimated to be positive and of similar magnitude to those reported in Table 4, though the effects are a little less precisely determined.

Still concering possible discrepancies due to hours differences, we also considered whether our results could be explained by the under-sampling of part-time workers in the NES. We did this in two ways. First, we included a variable measuring the minimum number of hours that had to be worked to earn more than the National Insurance lower earnings limit. We constructed two variables of this type; in one we divided the weekly earnings limit by the minimum in the Wages Council concerned while in the other we divided by average earnings. At no time did this variable alter the sign or magnitude of the measured minimum wage effects.

We also considered whether our results hold for alternative measures of employment, and report estimates using employment data from the Employment Gazette in columns (3) and (4) of Table 5. Again the results are very similar. In column (3) the impact of toughness on employment is positive and significant with a t-ratio of 2.00 . The estimated coeffcient on $\log$ (toughness) is somewhat smaller than before, but this is not surprising if the employment measure includes some workers who are not covered by the Wages Councils. When the toughness variable is instrumented it loses significance, although it retains a positive sign with an asymptotic $t$-ratio in excess of unity $(' t '=1.26)$. 
On the basis of the results in Tables 4 and 5 we conclude that our findings are relatively robust across alternative employment measures and to various specification changes and robustness checks. However, despite the fact that the models reported in Tables 4-6 do not appear to suffer from model misspecification via omitted dynamics (see the serial correlation tests), there is an issue of whether our results are contaminated by not considering the potential for dynamic minimum wage effects on employment (see Neumark and Wascher, 1992, who argue that minimum wage effects on employment may persist across time periods). To this end our final set of empirical results are dynamic employment functions that allow for minimum wage effects dated back to ( $t-2)$ to affect employment.

We report six dynamic employment functions in Table 6 . The equations differ in their dependent variable (the two employment variables and the total employee hours variable) and in whether or not toughness is instrumented. Whilst there are some noticable differences in the nature of the estimated employment functions (e.g. lagged dependent variables have a more important impact for the EG variable) they still paint an unambiguous pattern. Minimum wage effects are estimated to positive, and significantly so in some specifications. There remains no evidence of any negative impact of minimum wages on the employment patterns of Wages Council workers. Of course, it should be noted that we have only investigated the effect of the Wages Councils on employment in the affected industries; it is possible that employment in other industries is affected but it seems rather implausible and unlikely to think that these indirect effects could overturn the direct effects. Irrespective of specification and data definition, the effect of minimum wages on employment is always estimated to be non-negative and in many cases to be positive.

These results contrast markedly with Kaufman's (1989) study of the employment 
effects of the Wages Councils so it is probably worth commenting on differences between our study and his. First, there is a difference in the sample period used; most of his results are based on the 1970s. Secondly, the sample of Wages Council industries used are different. Kaufman concentrates on small manufacturing industries and excludes several of the large service-sector industries notably retail and catering. Curiously, he also seems to have included two industries in his sample, jute and paper box, in which the Wages Councils were abolished in 1969 yet almost all his observations come from the 1970s. We believe that our sample covers the vast bulk of workers in Wages Council industries so is likely to present a much more accurate picture of the effect of Wages Councils. Finally, there is a difference in methodology. Kaufman starts from the premise of the competitive model and adopts empirical specifications designed to find the negative effects predicted by that theory. We believe that prejudging the issue in that way is extremely dangerous and could well account for why his results differ from ours.

\section{Conclusion}

The late 1980s and early 1990s increases in the US federal minimum wage have generated a renewed interest in the economic effects of minimum wages. This has become even more the case since a number of recent empirical pieces based on these increases have reported very unconventional results, with minimum wage increases either not affecting employment or even raising it. Given the long-standing presumption in economics that minimum wages depress employment then it has proved somewhat difficult to provide a reasonable theoretical explanation of such findings.

In this paper we have presented a model of the labour market which we have argued 
can be usefully used for thinking about the likely effects of minimum wages on the labour market. We have not attempted to test our model against competing alternatives but we believe that it is intuitively plausible and it can do quite well in explaining the stylized facts about the effects of minimum wages. Using this theoretical framework, we have evaluated a number of possible empirical approaches to looking at the effect of minimum wages. Implementing the approaches that we favour to examine the effect of minimum wages in the UK, we find strong evidence that they have compressed the distribution of eamings and probably raised employment, the latter being a result that would be regarded as anomalous in a competitive model but one that can easily be explained in our framework.

Of course, the results reported here cast severe doubt on the UK Government's claim that the recent abolition of the Wages Councils in its 1993 Trade Union Reform and Employment Rights Bill could be justified on the grounds that they have traditionally hindered employment. According to our results it seems that the only likely impact of abolition will be increased inequality of eamings, coupled with no employment gains. 


\section{Appendix: Deriving Aggregate Employment}

In this Appendix we show how we can derive a relationship between employment, the spike and toughness which depends only on the following parameters of the model:

a) $\epsilon$, the elasticity of the marginal revenue product of labour.

b) $\theta$, the inverse of the elasticity of the supply curve facing the firm.

c) $\sigma$, the standard deviation of log wages in the absence of minimum wages.

d) $\mu$, the knock-on effect of the minimum wage further up the wage distribution.

e) $\rho$, the correlation between the wage shock and the labour supply shock.

The derivation of these results is rather tedious, relying on results about the means of truncated log-normal distributions (see Maddala, 1983) but there is nothing difficult about it.

First, consider the derivation of total employment. If we have a minimum wage $\mathrm{W}^{*}$ that induces $\left(\mathrm{X}_{+}, \mathrm{X}_{.}\right)$then average employment among unconstrained firms is given by:

$$
L_{I}=E\left(L_{1} \mid X_{i}>X_{+}\right)=W^{\frac{-\mu}{\theta+\epsilon}} \cdot E\left(U_{l}\right) \cdot E\left(X_{i}^{\frac{1-\rho}{\theta}}\right) \frac{1-\Phi\left(z_{+}-\sigma\left(\frac{1-\rho}{\theta}\right)\right)}{1-\Phi\left(z_{+}\right)}
$$

where $z_{+}=\frac{\ln X_{+}-\ln X}{\sigma}$ where $\ln X$ is the mean of $\ln X_{i}$ and $\sigma^{2}$ is the variance of $\ln X_{i}$.

For supply-constrained firms average employment is given by:

where $\ln Z=z$ and $Z=(\ln (X / X)) / \sigma$.

For demand-constrained firms average employment is given by: 


$$
\begin{aligned}
& L_{n}=E\left(L_{i} \mid X_{-}<X_{i}<X_{\uparrow}\right)= \\
& W^{\frac{-\mu}{\theta+a}} E\left(U_{j}\right) E\left(X_{i}^{\frac{1-p}{\theta}}\right) \cdot z_{+}^{\frac{\sigma}{\theta}} \cdot \frac{\Phi\left(z_{+}+\frac{\sigma p}{\theta}\right)-\Phi\left(z_{-}+\frac{\sigma p}{\theta}\right)}{\Phi\left(z_{+}\right)-\Phi\left(z_{-}\right)} e^{\frac{\sigma^{2}(2 p-1)}{2 \theta_{c}}} \\
& L_{m}=E\left(L_{i} \mid X_{i}<X\right)= \\
& W^{\frac{-\mu}{\theta+\epsilon}} E\left(U_{p}\right) E\left(X_{i}^{\frac{1-p}{\theta}}\right)(1+\theta)^{\frac{1}{\epsilon+\theta}} Z_{-}^{-\frac{0}{\theta}} \frac{\Phi\left(z_{-}-\sigma\left(\frac{1-p}{\theta}+\frac{1}{\epsilon}\right)\right)}{\Phi(z)} \cdot e^{\frac{\sigma^{2}}{2 \epsilon}\left(\frac{2(1-p)}{\theta}+\frac{1}{\epsilon}\right)}
\end{aligned}
$$

Combining them we have that average employment $\mathrm{L}$ is given by:

$$
L=\left[1-\Phi\left(z_{+}\right)\right] \cdot L_{I}+\left[\Phi\left(z_{+}\right)-\Phi\left(z_{-}\right)\right] \cdot L_{I I}+\Phi\left(z_{-}\right) \cdot L_{m I}
$$

which is a function of $z_{+}$and the average wage $W$. We will show that the proportion of workers being paid the minimum and the ratio of the minimum to the average wage is also a function of $z_{+}$. The proportion of workers being paid the minimum is given by:

$$
s=1-\frac{\left[1-\Phi\left(z_{t}\right)\right] L_{l}}{L}
$$

which is a function of $z_{+}$as claimed above.

Now consider how we can compute the average wage. A fraction s of workers are paid $\mathrm{W}^{*}$. Consider the average wage in unconstrained firms. We cannot take a simple average of $(10)$ as that would give us the average wage across firms. The average wage bill for an unconstrained firm is:

Dividing by (a1) gives us the average wage among unconstrained firms, $\mathrm{W}_{1}$ :

Now $W=(1-s) W_{1}+s W^{*}$ which from (a5) can be written as:

Using (12) to write $\mathrm{W}^{*}$ in terms of $\mathrm{W}$ and $\mathrm{z}_{+}$we can use (a8) to derive an expression for $\mathrm{W}$ 


$$
\begin{aligned}
& E\left(W_{l} L_{l} \mid X_{i}>X_{\uparrow}\right)= \\
& W_{0} E\left(U_{)} W^{\frac{(1-\mu)}{\theta+\epsilon}} E\left(X_{i}^{\frac{1-\rho}{\theta}}\right) E\left(X_{p}\right) \frac{1-\Phi\left(z_{+}-\sigma\left(1+\frac{1-\rho}{\theta}\right)\right)}{1-\Phi\left(z_{+}\right)} e^{\sigma^{2} \frac{(1-\rho)}{\theta}}\right. \\
& W_{I}=W_{0} W^{\frac{\mu e}{\theta+c}} X e^{\sigma^{2}\left(\frac{1}{2}+\frac{1-\rho}{\theta}\right)} \cdot \frac{1-\Phi\left(z_{+}-\sigma\left(1+\frac{1-\rho}{\theta}\right)\right)}{1-\Phi\left(z_{+}-\frac{\sigma(1-\rho)}{\theta}\right)} \\
& =W^{*} e^{-0 z_{+}+\sigma^{2}\left(\frac{1}{2}+\frac{1-\rho}{\theta}\right)} \cdot \frac{1-\Phi\left(z_{+}-\sigma\left(1+\frac{1-\rho}{\theta}\right)\right)}{1-\Phi\left(z_{+}-\frac{\sigma(1-\rho)}{\theta}\right)} \\
& W=W^{*}\left\{s+(1-s) e^{-\sigma z_{+}+\sigma^{2}\left(\frac{1}{2}+\frac{1-\rho}{\theta}\right)} \cdot \frac{1-\Phi\left(z_{+}-\sigma\left(1+\frac{1-\rho}{\theta}\right)\right)}{1-\Phi\left(z_{+}-\frac{\sigma(1-\rho)}{\theta}\right)}\right\}
\end{aligned}
$$

that can be substituted into (a4) to give an expression for employment in terms of $z_{+}$alone.

Similarly toughness is $\left(W^{*} / W\right)$ which, using (a5) and (a8) can also be written as a function of $z_{+}$. 


\section{$\underline{\text { References }}$}

Arellano, Manuel and Stephen Bond (1991) "Some tests of specification for panel data: Monte Carlo evidence and an application to employment equations", Review of Economic Studies, 58, 277-98.

Brown, Charles., Curtis Gilroy and Andrew Kohen (1982) "The effect of the minimum wage on employment and unemployment", Joumal of Economic Literature, 20, 487-528.

Brown, Charles and James Medoff (1989) "The employer size-wage effect", Loumal of Political Economy, 97, 1027-1059.

Burdett, Kenneth and Dale Mortensen (1989) "Equilibrium wage differentials and employer size", forthcoming Review of Economic Studies.

Calvo, Guillermo and Stanislaw Wellisz (1979) "Hierarchy, ability and income distribution", Journal of Political Economy, Part 1, 87, 991-1010.

Card, David (1992a) "Using regional variations in wages to measure the effects of the federal minimum wage", Industrial and Labor Relations Review, 46, 22-37.

Card, David (1992b) "Do minimum wages reduce employment? A case study of California, 1987-89", Industrial and Labor Relations Review, 46, 38-54.

Card, David and Alan Krueger (1993) "Minimum wages and employment: A case study of the fast food industry in New Jersey and Pennsylvania", Princeton University Industrial Relations Section Discussion Paper No. 315.

Card, David, Lawrence Katz and Alan Krueger (1993) "Comment on David Neumark and William Wascher, "Employment effects of minimum and sub-minimum wages: Panel data on state minimum wage laws", Princeton University Industrial Relations Section Discussion Paper No. 316.

Dickens, William and Lawrence Katz (1987) "Inter industry wage differences and industry characteristics", in Kevin Lang and Jonathan Leonard (eds.), Unemployment and the Structure of Labour Markets, Oxford: Basil Blackwell.

Dickens, Richard, Paul Gregg, Stephen Machin, Alan Manning and Jonathan Wadsworth (1993) "Wages Councils: Was there a case for abolition", forthcoming British Journal of Industrial Relations, December 1993.

Dixit, Avinash and Joseph Stiglitz (1977) "Monopolistic Competition and Optimum Product Diversity", American Economic Review, 67, 297-308. 
Freeman, Richard (1980) "Economic determinants of geographic and individual variation in the labor market position of young persons", in R.Freeman and D.Wise (eds.), The Youth Labour Market Problem: its Nature. Causes and Consequences.

Holzer Harry, Lawrence Katz and Alan Krueger (1991) "Job queues and wages", Quarterly Joumal of Economics, 106, 739-68.

Katz, Lawrence and Alan Krueger (1992) "The Effect of the Minimum Wage in the fast food industry", Industrial and Labor Relations Review, 46, 6-21.

Kaufman, Roger (1989) "The effects of statutory minimum rates of pay on employment in Great Britain", Economic Joumal, 99, 1040-1053.

Lester, Richard (1960) "Employment effects of minimum wages", Industrial and Labor Relations Review, 13, 254-64.

Machin, Stephen and Alan Manning (1992) "Minimum Wages, Wage Dispersion and Employment: Evidence from the UK Wages Councils", Discussion Paper No.80, Centre for Economic Performance, London School of Economics, forthcoming Industrial and Labor Relations Review.

Machin, Stephen, Alan Manning and Stephen Woodland (1993) "Are workers paid their marginal product? Evidence from a low wage labour market", Discussion Paper No.93-09, University College London.

Maddala, G. (1983) Limited-dependent and qualitative variables in econometrics, Cambridge University Press.

Meyer, Robert and David Wise (1983a) "The effects of the minimum wage on the employment and earnings of youth", Joumal of Labor Economics, 1, 66-100.

Meyer, Robert and David Wise (1983b) "Discontinuous distributions and missing persons: the minimum wage and unemployed youth", Econometrica, 61, 1677-1698.

Neumark, David and William Wascher (1992) "Employment effects of minimum and subminimum wages: Panel data on state minimum wage laws", Industrial and Labor Relations Review, 46, 55-81.

Nickell, Stephen and Sushil Wadhwani (1990) "Insider forces and wage determination", Economic Joumal, 100, 496-509.

Sullivan, Daniel (1989) "Monopsony power in the market for nurses", Joumal of Law and Economics, 32, S135-S178. 
Teulings, Coen (1992) "The effect of minimum wages on wage distribution and employment using non-discrete factor production functions", unpublished, University of Amsterdam. 


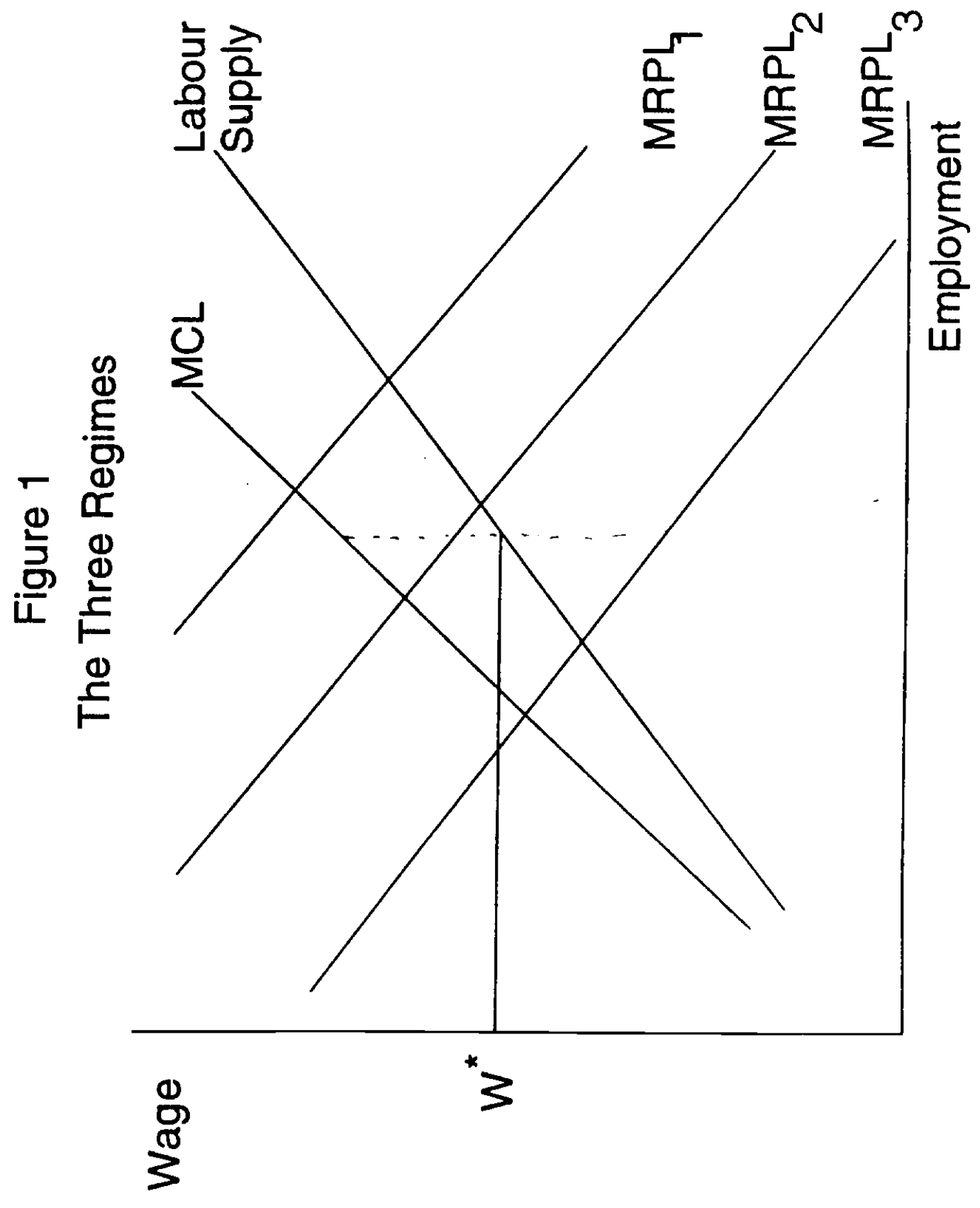




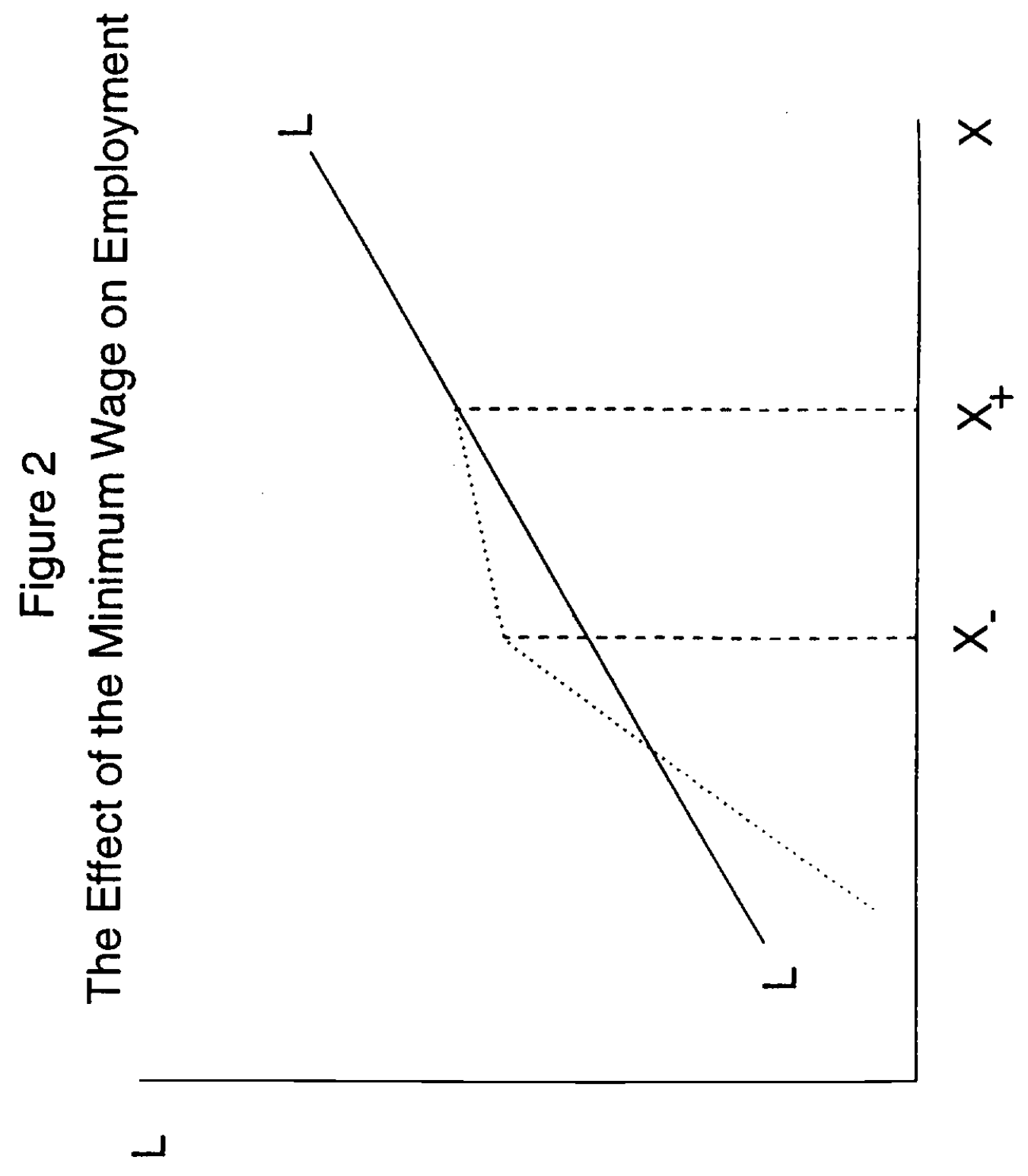




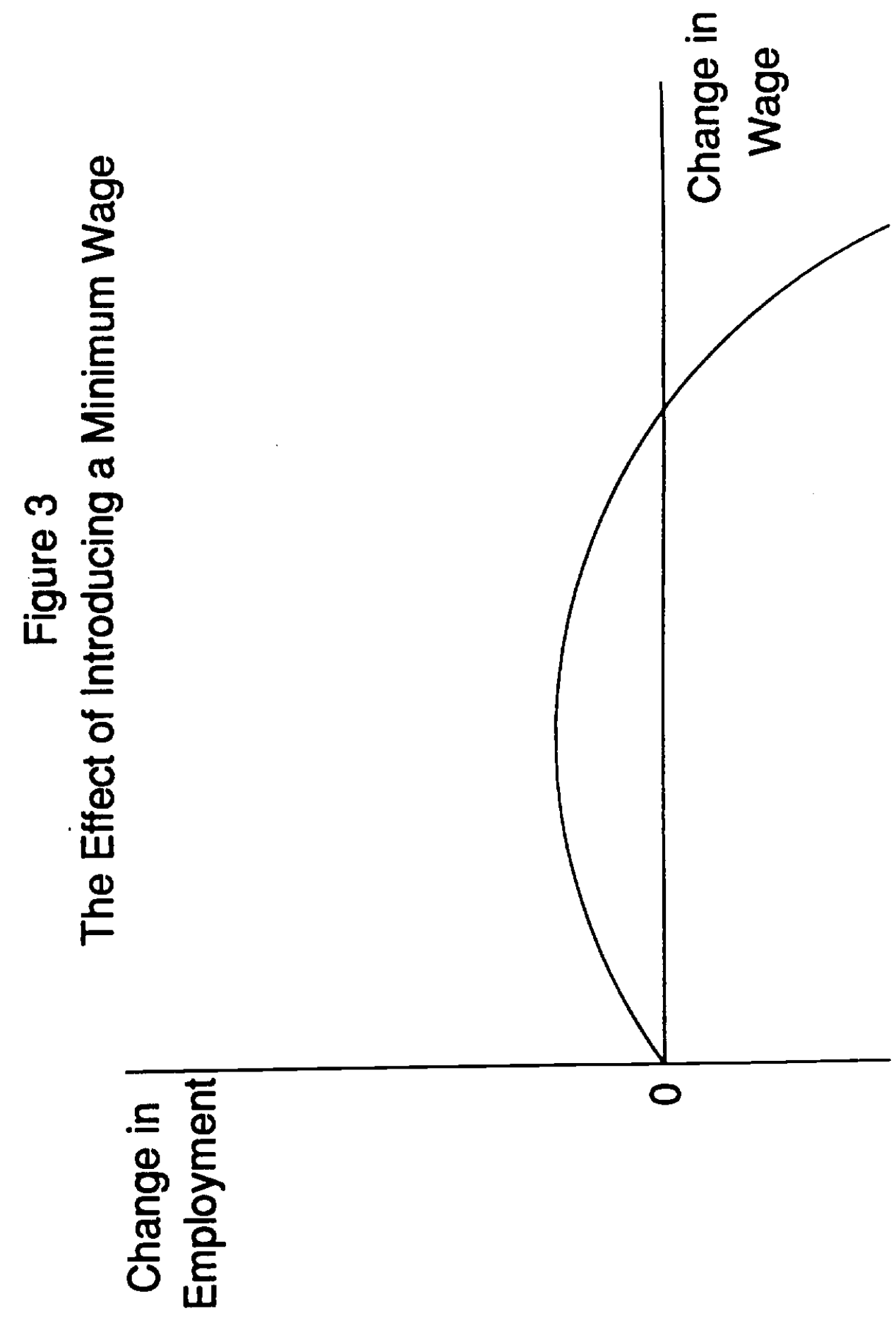


Figure 4

The Toughness of the Wages Councils:

Median of Ratio of Minimum to Average Hourly Earnings, 1975-1990

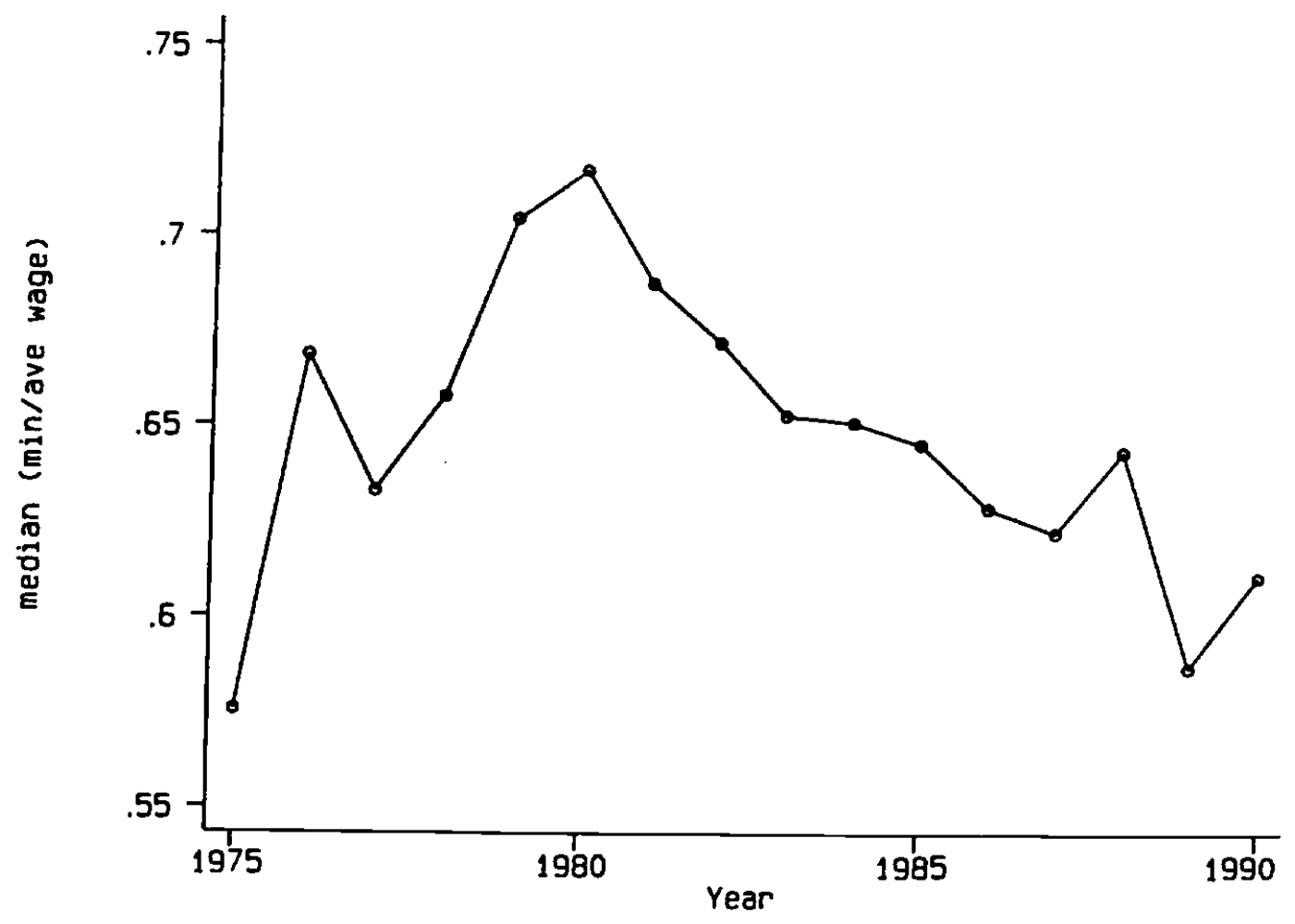


Figure 5

Changes in Log(Employment) and Changes in Log(Toughness)

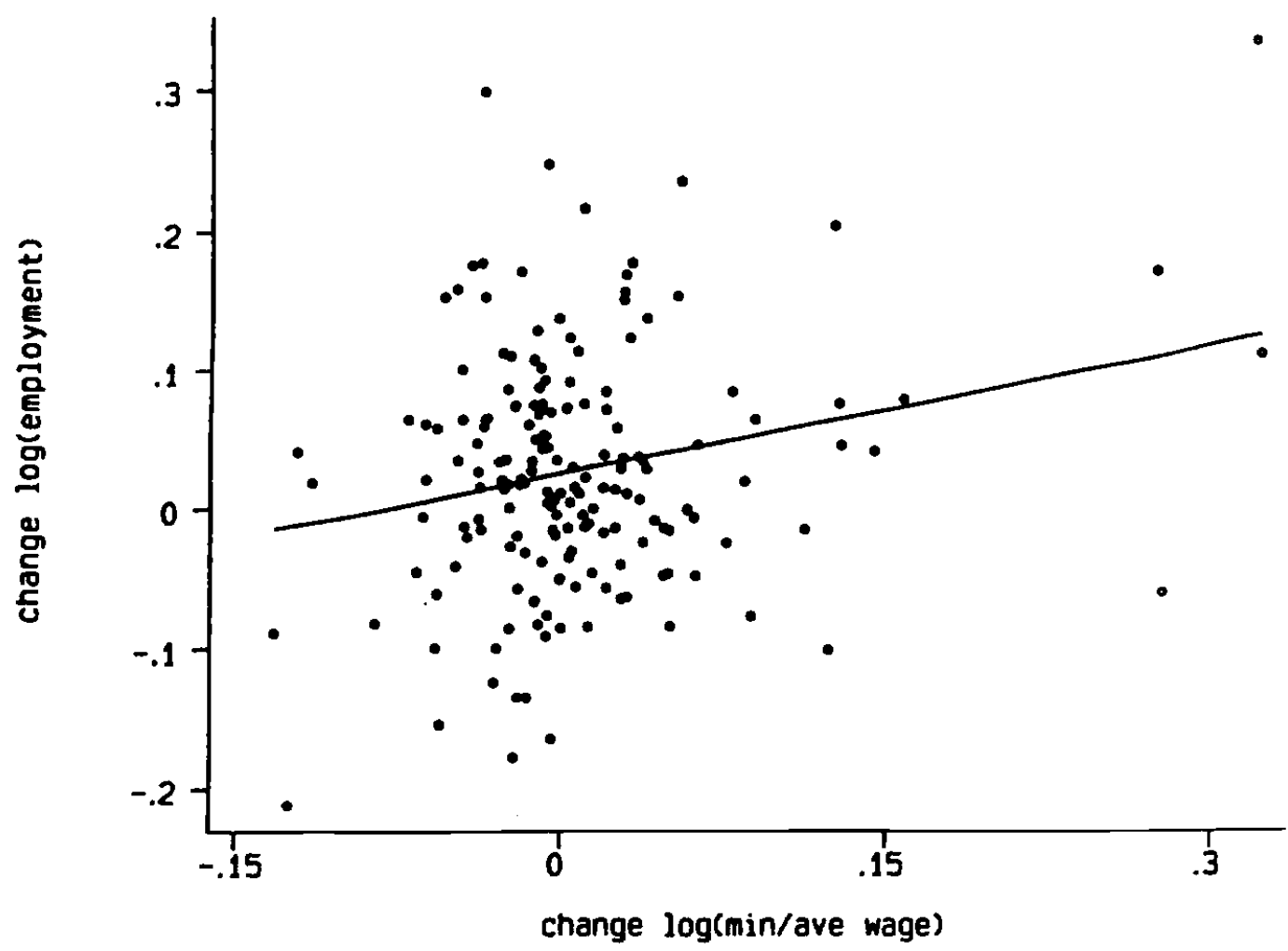

Notes.

1. Based on New Eamings Survey data described in Table 2. The regression line is from a regression of the change in log(employment) on the change in the . $\log$ (minimum/average) (standard errors in brackets):

Change in $\log ($ employment $)=.026+.305$ Change in $\log$ (minimum/average)

$$
(.006)(.137)
$$

2. An analogous regression estimated by robust regression methods to downgrade the importance of potential outliers was:

Change in log(employment) $=.022+.226$ Change in log(minimum/average)

$$
(.006)(.099)
$$


Table 1

Simulations of the Optimal Minimum Wage

The Effects of Variation in $\theta$

\begin{tabular}{|c|c|c|c|c|}
\hline$\theta$ & $\begin{array}{c}\text { optimal } \\
\text { spike }\end{array}$ & $\begin{array}{c}\text { optimal } \\
\text { toughness }\end{array}$ & $\begin{array}{c}\text { employment } \\
\text { gain }\end{array}$ & $\begin{array}{c}\text { wage } \\
\text { gain }\end{array}$ \\
\hline 0.05 & 0.0 & 0.0 & 0.0 & 0.0 \\
\hline 0.10 & 0.2 & 40.3 & 0.0 & 0.0 \\
\hline 0.15 & 3.8 & 55.9 & 0.1 & 0.2 \\
\hline 0.20 & 12.1 & 66.3 & 0.5 & 0.8 \\
\hline 0.25 & 21.9 & 73.5 & 1.3 & 1.9 \\
\hline
\end{tabular}

The Effects of Variation in $\sigma$

\begin{tabular}{||c|c|c|c|c||}
\hline \hline$\sigma$ & $\begin{array}{c}\text { optimal } \\
\text { spike }\end{array}$ & $\begin{array}{c}\text { optimal } \\
\text { toughness }\end{array}$ & $\begin{array}{c}\text { employment } \\
\text { gain }\end{array}$ & $\begin{array}{c}\text { wage } \\
\text { gain }\end{array}$ \\
\hline 0.1 & 72.9 & 98.2 & 8.2 & 6.7 \\
\hline 0.2 & 34.1 & 86.8 & 2.2 & 3.1 \\
\hline 0.3 & 12.1 & 66.3 & 0.5 & 0.8 \\
\hline 0.4 & 3.3 & 44.0 & 0.1 & 0.1 \\
\hline 0.5 & 0.7 & 25.5 & 0.0 & 0.0 \\
\hline
\end{tabular}


Table 1 (continued)

The Effects of Variation in $\mu$

\begin{tabular}{|c|c|c|c|c|}
\hline$\mu$ & $\begin{array}{c}\text { optimal } \\
\text { spike }\end{array}$ & $\begin{array}{c}\text { optimal } \\
\text { toughness }\end{array}$ & $\begin{array}{c}\text { employment } \\
\text { gain }\end{array}$ & $\begin{array}{c}\text { wage } \\
\text { gain }\end{array}$ \\
\hline-0.5 & 30.7 & 79.0 & 1.6 & 3.2 \\
\hline 0.0 & 12.1 & 66.3 & 0.5 & 0.8 \\
\hline 0.5 & 3.7 & 55.3 & 0.2 & 0.1 \\
\hline 1.0 & 1.3 & 48.5 & 0.0 & 0.0 \\
\hline
\end{tabular}

The Effects of Variation in $\epsilon$

\begin{tabular}{||c|c|c|c|c|}
\hline$\epsilon$ & $\begin{array}{c}\text { optimal } \\
\text { spike }\end{array}$ & $\begin{array}{c}\text { optimal } \\
\text { toughness }\end{array}$ & $\begin{array}{c}\text { employment } \\
\text { gain }\end{array}$ & $\begin{array}{c}\text { wage } \\
\text { gain }\end{array}$ \\
\hline 1.0 & 12.4 & 66.7 & 0.3 & 0.9 \\
\hline 2.0 & 12.1 & 66.3 & 0.5 & 0.8 \\
\hline 3.0 & 11.9 & 66.0 & 0.6 & 0.7 \\
\hline 4.0 & 11.7 & 65.8 & 0.7 & 0.7 \\
\hline
\end{tabular}

Notes.

1. In all tables only one parameter is varied from the base case. In the base case we use the parameters $\sigma=0.3, \mu=0.0, \epsilon=2, \theta=0.2$.

2. The numbers given refer to percentage points. 
Table 2

Summary of Wages Council data

\begin{tabular}{|c|c|c|c|c|}
\hline Wages Council & $\begin{array}{l}\text { Average } \\
\text { Toughneas }\end{array}$ & $\begin{array}{c}\text { Average } \\
\text { Employment, } \\
\text { NES }\end{array}$ & $\begin{array}{c}\text { Average } \\
\text { Employment, } \\
\text { EG }\end{array}$ & $\begin{array}{l}\text { Correlation } \\
\text { between NES and } \\
\text { EG series }\end{array}$ \\
\hline \multicolumn{5}{|l|}{ Councils in Sample 1975-1990 } \\
\hline $\begin{array}{l}\text { Licensed Residential } \\
\text { Establishment, Male }\end{array}$ & 0.6049 & 503 & 103906 & 0.3814 \\
\hline $\begin{array}{l}\text { Licensed non-Residential } \\
\text { Establishment, Male }\end{array}$ & 0.6481 & 461 & 126438 & 0.4749 \\
\hline $\begin{array}{l}\text { Unlicensed Place of Refreshment, } \\
\text { Male }\end{array}$ & 0.5965 & 311 & 77544 & 0.9697 \\
\hline $\begin{array}{l}\text { Licensed Residential } \\
\text { Establishment, Female }\end{array}$ & 0.7996 & 636 & 167569 & 0.7355 \\
\hline $\begin{array}{l}\text { Licensed non-Residential } \\
\text { Establishment, Female }\end{array}$ & 0.8864 & 748 & 258456 & 0.8253 \\
\hline $\begin{array}{l}\text { Unlicensed Place of Refreshment, } \\
\text { Female }\end{array}$ & 0.7898 & 425 & 130788 & 0.9619 \\
\hline \multicolumn{5}{|l|}{ Councils in Sample 1975-1981 } \\
\hline Clothing Manufacture, Male & 0.5104 & 313 & 49586 & 0.7372 \\
\hline Retail Food \& Allied Trades, Malc & 0.5552 & 1348 & 223186 & -0.2326 \\
\hline Retail Trades (Non-Food), Male & 0.5180 & 2537 & 406471 & -0.0882 \\
\hline Clothing Manufacture, Female & 0.7766 & 1441 & 212557 & 0.9346 \\
\hline $\begin{array}{l}\text { Retail Food \& Allied Trades, } \\
\text { Female }\end{array}$ & 0.8617 & 2238 & 382114 & -0.2035 \\
\hline Retail Trades (Non-Food), Female & 0.8044 & 5322 & 850657 & -0.2761 \\
\hline \multicolumn{5}{|l|}{ Councils in Sample 1982-1990 } \\
\hline Clothing Manufacture, Male & 0.4446 & 236 & 41433 & -0.3014 \\
\hline Retail Food \& Allied Trades, Male & 0.5839 & 1579 & 245478 & -0.2044 \\
\hline Retsil Trades (Non-Food), Male & 0.4982 & 2531 & 357456 & 0.9206 \\
\hline Clothing Manufacture, Female & 0.7186 & 1137 & 164689 & -0.0274 \\
\hline $\begin{array}{l}\text { Retail Food \& Allied Trades, } \\
\text { Femalc }\end{array}$ & 0.8805 & 2824 & 465733 & 0.6364 \\
\hline Retail Trades (Non-Food), Female & 0.7688 & 5117 & 760478 & 0.7828 \\
\hline
\end{tabular}


Table 2 (continued)

\begin{tabular}{|c|c|c|c|}
\hline Wages Council & $\begin{array}{l}\text { Average Change } \\
\text { in } \\
\text { Log(Toughneas) }\end{array}$ & $\begin{array}{c}\text { Average Change in } \\
\text { Log(Employment), } \\
\text { NES }\end{array}$ & $\begin{array}{c}\text { Average Change in } \\
\text { Log(Employment), } \\
\text { EG }\end{array}$ \\
\hline \multicolumn{4}{|l|}{ Councils in Sumple 1975-1990 } \\
\hline $\begin{array}{l}\text { Licensed Residential } \\
\text { Establishment, Male }\end{array}$ & 0.0063 & 0.0173 & 0.0134 \\
\hline $\begin{array}{l}\text { Licensed non-Reaidential } \\
\text { Eatablishment, Male }\end{array}$ & 0.0114 & 0.0237 & 0.0203 \\
\hline $\begin{array}{l}\text { Unlicensed Place of Refreshment, } \\
\text { Male }\end{array}$ & 0.0249 & 0.0617 & 0.0503 \\
\hline $\begin{array}{l}\text { Licensed Residential } \\
\text { Eatablishment, Fermale }\end{array}$ & 0.0001 & 0.0437 & 0.0172 \\
\hline $\begin{array}{l}\text { Licensed non-Residential } \\
\text { Establishment, Female }\end{array}$ & 0.0084 & 0.0537 & 0.0277 \\
\hline $\begin{array}{l}\text { Unlicensed Place of Refrethment, } \\
\text { Female }\end{array}$ & 0.0264 & 0.0769 & 0.0373 \\
\hline \multicolumn{4}{|l|}{ Councila in Sample 1975-1981 } \\
\hline Clothing Manufacture, Male & 0.0060 & -0.0307 & -0.0387 \\
\hline Retail Food \& Allied Trades, Male & 0.0267 & 0.0415 & -0.0003 \\
\hline Retail Trades (Non-Food), Male & 0.0216 & 0.0345 & -0.0115 \\
\hline Clothing Manufacture, Female & 0.0074 & -0.0330 & -0.0442 \\
\hline $\begin{array}{l}\text { Retail Food \& Allied Trades, } \\
\text { Female }\end{array}$ & 0.0233 & 0.0510 & -0.0096 \\
\hline Retail Trades (Non-Food), Female & 0.0137 & 0.0352 & -0.0104 \\
\hline \multicolumn{4}{|l|}{ Councils in Sample 1982-1990 } \\
\hline Clothing Manufacture, Male & -0.0144 & -0.0060 & -0.0106 \\
\hline Retail Food \& Allied Trades, Male & 0.0085 & -0.0108 & 0.0078 \\
\hline Retail Tradea (Non-Food), Male & -0.0115 & 0.0235 & 0.0257 \\
\hline Clothing Manufacture, Female & -0.0154 & -0.0134 & -0.0166 \\
\hline $\begin{array}{l}\text { Retail Food \& Allied Trades, } \\
\text { Female }\end{array}$ & -0.0053 & 0.0056 & 0.0159 \\
\hline Retail Trades (Non-Food), Female & -0.0111 & 0.0180 & 0.0140 \\
\hline
\end{tabular}

Notes.

1. The 1975-81 and 1982-90 Councils are treatod sepparately as a consequence of the 1980 change in the Standard Industrial Classification (i.e. pre-1980 and post-1980 definitions did not match after the change) which was adopted in the New Eamings Survey data in 1982.

2. NES refers to New Eamings Survey and EG to Employment Gazette.

3. Toughness is defined as the ratio of the minimum hourly wage to the average hourly wage. 
Table 3

Effects of Minimum Wages on the Wage Distribution

Dependent variable:

$\Delta$ ith percentile / average of log real hourly earnings distribution

\begin{tabular}{||l|c|c|}
\hline Dependent Variable & $\begin{array}{c}\text { Coefficient (standard } \\
\text { error) on } \Delta \text { Log(real } \\
\text { minimum hourly wage) }\end{array}$ & $\begin{array}{c}\text { Test for } \\
\text { Serial } \\
\text { Correlation }\end{array}$ \\
\hline$\Delta 10$ th percentile & $.231(.058)$ & -.698 \\
\hline$\Delta$ 20th percentile & $.252(.067)$ & 1.288 \\
\hline$\Delta 30$ th percentile & $.146(.054)$ & .318 \\
\hline$\Delta 40$ th percentile & $.089(.051)$ & .042 \\
\hline$\Delta 50$ th percentile & $.014(.045)$ & -.084 \\
\hline$\Delta 60$ th percentile & $.017(.050)$ & -.024 \\
\hline$\Delta 70$ th percentile & $-.023(.052)$ & .625 \\
\hline$\Delta 80$ th percentile & $-.062(.062)$ & 1.213 \\
\hline$\Delta 90$ th percentile & $-.062(.090)$ & 1.434 \\
\hline$\Delta$ average & $.128(.048)$ & 1.153 \\
\hline
\end{tabular}

Notes:

1. Sample size: 204; Estimation period: 1976-90. Regressions weighted by employment in industry-year cell.

2. Heteroskedastic consistent standard errors in parentheses.

3. Time dummies included in all specifications.

4. Serial correlation test is an $\mathbf{N}(0,1)$ statistic for first-differenced panel data models as described in Arellano and Bond (1991). 
Table 4

Minimum Wages and Employment in

18 Covered Wages Council Industries 1978-90, New Earnings Survey Employment Data

Dependent Variable:

$\Delta \log (\text { Employment, NES) })_{k}$

\begin{tabular}{|c|c|c|c|c|c|c|c|}
\hline & \multicolumn{4}{|c|}{ Log of Toughness not instrumented } & \multicolumn{3}{|c|}{$\begin{array}{l}\text { Log of Toughness instrumented } \\
\text { using } \log \text { of Real Minimum } \\
\text { Wage dated } t, t-1, t-2\end{array}$} \\
\hline & (1) & (2) & (3) & (4) & (5) & (6) & (7) \\
\hline$\Delta \log ($ Toughness) & $\begin{array}{c}.313 \\
(.136)\end{array}$ & $\begin{array}{l}.298 \\
(.139)\end{array}$ & $\begin{array}{c}.409 \\
(.189)\end{array}$ & $\begin{array}{c}.288 \\
(.144)\end{array}$ & $\begin{array}{c}.540 \\
(.234)\end{array}$ & $\begin{array}{c}.436 \\
(.247)\end{array}$ & $\begin{array}{l}.455 \\
(.274)\end{array}$ \\
\hline Retail sector & & $\begin{array}{l}-.032 \\
(.008) \\
\end{array}$ & $\begin{array}{l}-.023 \\
(.007) \\
\end{array}$ & $\begin{array}{l}-.031 \\
(.009) \\
\end{array}$ & & $\begin{array}{l}-.032 \\
(.009) \\
\end{array}$ & $\begin{array}{l}-.032 \\
(.014) \\
\end{array}$ \\
\hline Clothing sector & & $\begin{array}{l}-.066 \\
(.009)\end{array}$ & $\begin{array}{l}-.031 \\
(.014)\end{array}$ & $\begin{array}{l}-.065 \\
(.010)\end{array}$ & & $\begin{array}{l}-.063 \\
(.009)\end{array}$ & $\begin{array}{l}-.024 \\
(.007)\end{array}$ \\
\hline $\begin{array}{l}\Delta \log (\text { Sales); } \\
\text { (Instrumented) }\end{array}$ & & & $\begin{array}{l}.506 \\
(.251)\end{array}$ & & & & $\begin{array}{l}.465 \\
(.253)\end{array}$ \\
\hline$\Delta \log (\text { Sales })_{j, 1-2}$ & & & & $\begin{array}{c}.060 \\
(.209)\end{array}$ & & & \\
\hline Year dummies & Yes & Yes & Yes & Yes & Yes & Yes & Yes \\
\hline Serial Correlation & 1.658 & .367 & -.446 & .438 & 1.556 & .319 & -.366 \\
\hline
\end{tabular}

Notes.

1. Sample size: 138; Estimation period: 1978-90.

2. Heteroskedastic consistent standard errors in parentheses.

3. The serial correlation test is an $\mathbf{N}(0,1)$ statistic for first-differenced panel data models as described in Arellano and Bond (1991). 
Table 5

Minimum Wages and Employment in

18 Covered Wages Council Industries 1978-90,

New Earnings Survey Employee Hours Data (Columns 1 and 2)

and Employment Gazette Employment Data (Columns 3 and 4)

Dependent Variable:

$\Delta \log$ (Total Employee Hours, NES)jt (Columns 1 and 2)

$\Delta \log (\text { Employment, EG) } \text { (Columns } 3 \text { and } 4)^{2}$

\begin{tabular}{|c|c|c|c|c|}
\hline & $\begin{array}{l}\text { Log of } \\
\text { toughness not } \\
\text { instrumented }\end{array}$ & $\begin{array}{c}\text { Log of } \\
\text { toughness } \\
\text { instrumented }\end{array}$ & $\begin{array}{l}\text { Log of } \\
\text { toughness not } \\
\text { instrumented }\end{array}$ & $\begin{array}{c}\text { Log of } \\
\text { Toughness } \\
\text { instrumented }\end{array}$ \\
\hline & (1) & (2) & (3) & (4) \\
\hline$\Delta \log (T$ oughness) & $\begin{array}{r}.338 \\
(.193) \\
\end{array}$ & $\begin{array}{r}.417 \\
(.287) \\
\end{array}$ & $\begin{array}{c}.143 \\
(.072)\end{array}$ & $\begin{array}{r}.152 \\
(.121) \\
\end{array}$ \\
\hline Retail sector & $\begin{array}{l}-.026 \\
(.008)\end{array}$ & $\begin{array}{l}-.026 \\
(.008) \\
\end{array}$ & $\begin{array}{l}-.017 \\
(.004)\end{array}$ & $\begin{array}{l}-.017 \\
(.004)\end{array}$ \\
\hline Clothing sector & $\begin{array}{l}-.016 \\
(.012) \\
\end{array}$ & $\begin{array}{l}-.017 \\
(.012) \\
\end{array}$ & $\begin{array}{l}-.042 \\
(.008) \\
\end{array}$ & $\begin{array}{l}-.041 \\
(.008) \\
\end{array}$ \\
\hline $\begin{array}{l}\Delta \log (\text { Sales) } \\
\text { (Instrumented) }\end{array}$ & $\begin{array}{r}.709 \\
(.228) \\
\end{array}$ & $\begin{array}{c}.633 \\
(.233) \\
\end{array}$ & $\begin{array}{r}.216 \\
(.191) \\
\end{array}$ & $\begin{array}{c}.201 \\
(.182) \\
\end{array}$ \\
\hline Year dummies & Yes & Yes & Yes & Yes \\
\hline Serial Correlation & -.270 & -.183 & .686 & 1.556 \\
\hline
\end{tabular}

Notes.

1. As for Table 4. 
Table 6

Dynamic Employment Functions: Minimum Wages and Employment in 18 Covered Wages Council Industries 1978-90, New Earnings Survey Data (Columns 1-4) and Employment Gazette Employment Data (Columns 5 and 6)

Dependent Variable:

$\Delta \log ($ Total Employment, NES) $\quad$ (Columns 1 and 2)

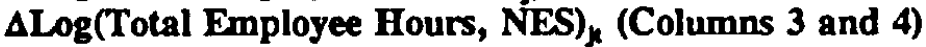

$\Delta \log (\text { Employment, EG) })_{k}($ Columns 5 and 6$)$

\begin{tabular}{|c|c|c|c|c|c|c|}
\hline & $\begin{array}{c}\text { Log of } \\
\text { toughneas } \\
\text { not } \\
\text { instrumented }\end{array}$ & $\begin{array}{c}\log \text { of } \\
\text { toughnes: } \\
\text { instrumented }\end{array}$ & $\begin{array}{c}\text { Log of } \\
\text { toughness } \\
\text { not } \\
\text { instrumented }\end{array}$ & $\begin{array}{c}\text { Log of } \\
\text { toughneas } \\
\text { instrumented }\end{array}$ & $\begin{array}{c}\text { Log of } \\
\text { toughness } \\
\text { not } \\
\text { instrumented }\end{array}$ & $\begin{array}{l}\log \text { of } \\
\text { Toughness } \\
\text { instrumen- } \\
\text { ced }\end{array}$ \\
\hline & (1) & (2) & (3) & (4) & (5) & (6) \\
\hline$\Delta \log$ (Toughness); & $\begin{array}{c}.430 \\
(.211)\end{array}$ & $\begin{array}{c}.342 \\
(.275)\end{array}$ & $\begin{array}{c}.270 \\
(.186)\end{array}$ & $\begin{array}{c}.197 \\
(.261)\end{array}$ & $\begin{array}{c}.085 \\
(.055)\end{array}$ & $\begin{array}{c}.023 \\
(.063)\end{array}$ \\
\hline$\Delta \log \left(T_{0 u g h n e s s}\right)_{\text {s, }-1}$ & $\begin{array}{c}.136 \\
(.095)\end{array}$ & $\begin{array}{c}.240 \\
(.144)\end{array}$ & $\begin{array}{c}.129 \\
(.075)\end{array}$ & $\begin{array}{c}.300 \\
(.132)\end{array}$ & $\begin{array}{l}-.028 \\
(.064)\end{array}$ & $\begin{array}{l}-.061 \\
(.070)\end{array}$ \\
\hline$\Delta \log (\text { Toughness })_{j,-2}$ & $\begin{array}{l}.144 \\
(.061)\end{array}$ & $\begin{array}{r}.298 \\
(.122) \\
\end{array}$ & $\begin{array}{c}.207 \\
(.112) \\
\end{array}$ & $\begin{array}{r}.448 \\
(.178) \\
\end{array}$ & $\begin{array}{c}.113 \\
(.036) \\
\end{array}$ & $\begin{array}{c}.203 \\
(.076) \\
\end{array}$ \\
\hline Retail sector & $\begin{array}{l}-.028 \\
(.008)\end{array}$ & $\begin{array}{l}-.027 \\
(.009)\end{array}$ & $\begin{array}{l}-.020 \\
(.008)\end{array}$ & $\begin{array}{l}-.025 \\
(.008)\end{array}$ & $\begin{array}{l}-.011 \\
(.003)\end{array}$ & $\begin{array}{l}-.009 \\
(.003)\end{array}$ \\
\hline Clothing sector & $\begin{array}{l}-.038 \\
(.019)\end{array}$ & $\begin{array}{l}-.032 \\
(.018)\end{array}$ & $\begin{array}{l}-.010 \\
(.014)\end{array}$ & $\begin{array}{l}-.008 \\
(.015)\end{array}$ & $\begin{array}{l}-.024 \\
(.006)\end{array}$ & $\begin{array}{l}-.019 \\
(.005)\end{array}$ \\
\hline $\begin{array}{l}\text { Sales growth } \\
\text { (Instrumented) }\end{array}$ & $\begin{array}{r}.432 \\
(.245) \\
\end{array}$ & $\begin{array}{r}.355 \\
(.238) \\
\end{array}$ & $\begin{array}{r}.498 \\
(.148) \\
\end{array}$ & $\begin{array}{c}.455 \\
(.173) \\
\end{array}$ & $\begin{array}{r}.102 \\
(.088) \\
\end{array}$ & $\begin{array}{c}.107 \\
(.086) \\
\end{array}$ \\
\hline $\begin{array}{l}\text { Dependent } \\
\text { variable }_{\mathrm{j}, \mathrm{t}-1}\end{array}$ & $\begin{array}{c}.194 \\
(.188) \\
\end{array}$ & $\begin{array}{c}.165 \\
(.190) \\
\end{array}$ & $\begin{array}{c}.270 \\
(.166) \\
\end{array}$ & $\begin{array}{c}.150 \\
(.175) \\
\end{array}$ & $\begin{array}{c}.606 \\
(.232) \\
\end{array}$ & $\begin{array}{c}.627 \\
(.246) \\
\end{array}$ \\
\hline $\begin{array}{l}\text { Dependent } \\
\text { variable }_{, t \cdot 2}\end{array}$ & $\begin{array}{l}-.239 \\
(.149) \\
\end{array}$ & $\begin{array}{l}-.156 \\
(.161) \\
\end{array}$ & $\begin{array}{c}.034 \\
(.149) \\
\end{array}$ & $\begin{array}{l}-.011 \\
(.144) \\
\end{array}$ & $\begin{array}{l}-.023 \\
(.276) \\
\end{array}$ & $\begin{array}{c}.010 \\
(.294) \\
\end{array}$ \\
\hline Year dummies & Yes & Yes & Yes & Yes & Yes & Yes \\
\hline Serial Correlation & 1.554 & 1.092 & .264 & .347 & -.473 & -.748 \\
\hline
\end{tabular}

Notes.

1. As for Table 4 .

2. Due to bias on coefficient on lagged dependent variable dated $(t-1)$ in firstdifferenced panel data models it is instrumented using values of itself dated $(t-2)$ as instruments (with coefficients in the instrumenting equation allowed to differ in each cross-section). 